\title{
IMPLEMENTASI RENCANA PELAKSANAAN PEMBELAJARAN (RPP) YANG BERKARAKTER PADA MATA PELAJARAN IPS TERPADU
}

\author{
Nining Andriani \\ Dosen Prodi Pendidikan Ekonomi, FKIP Universitas Samawa \\ Email: andrianinning@yahoo.co.id
}

\begin{abstract}
Abstrak
Rencana pelaksanaan pembelajaran yang berkarakter sangat diperlukan sejalan dengan beranekaragam corak perkembangan media pembelajaran serta sumber belajar disekitar sekolah yang dapat dimanfaatkan oleh guru dalam menunjang proses pembelajaran. Berdasarkan hasil penelitian dapat disimpulkan bahwa kemampuan guru dalam menyusun RPP berkarakter pada pelajaran IPS Terpadu belum mampu dilaksanakan dengan baik dan nilai karakter yang diharapkan pada RPP berkarakter hanya dicantumkan tetapi tidak diimplementasikan pada saat proses belajar-mengajar berlangsung. Guru belum dapat memilih nilai-nilai karakter yang sesuai dengan visinya, pemahaman guru tentang konsep pendidikan karakter yang masih belum menyeluruh, guru belum dapat memilih nilai-nilai karakter yang sesuai dengan mata pelajaran yang diampunya, guru belum memiliki kompetensi yang memadai untuk mengintegrasikan nilai-niai karakter pada mata pelajaran yang diampunya, dan guru belum dapat menjadi teladan atas nilai-nilai karakter yang dipilihnya.
\end{abstract}

Kata Kunci : Guru, RPP dan Berkarakter

\section{PENDAHULUAN}

Pendidikan menduduki peranan yang sangat penting dalam segala aspek kehidupan manusia. Pendidikan merupakan wahana untuk meningkatkan dan mengembangkan kualitas sumber daya manusia, baik itu bagi seorang guru maupun peserta didik itu sendiri. Sekolah adalah tempat menuntut ilmu agar dapat melangsungkan ke kehidupan yang lebih baik lagi. Perencanaan adalah pemikiran sebelum pelaksanaan sesuatu tugas. Jadi Perencanaan Pembelajaran berarti pemikiran tentang penerapan prinsip-prinsip umum mengajar tersebut di dalam pelaksanaan tugas mengajar dalam suatu situasi interaksi gurumurid, baik di dalam kelas maupun di luar kelas.

Adanya perencanaan, guru harus mampu memberikan pelajaran dengan baik, seorang guru dapat menghadapi situasi di dalam kelas secara tegas, mantap dan fleksibel. Membuat perencanaan yang baik, maka seorang akan tumbuh menjadi guru yang baik dan profesional. Seorang guru bisa menjadi guru profesional adalah berkat kemampuan, berkat pengalaman dan akibat dari hasil belajar yang terus menerus, walaupun faktor bakat ikut pula berpengaruh. Sesuai dengan ketentuan kurikulum pendidikan yang berlaku saat ini, guru harus mampu membuat rencana pelaksanaan pembelajaran yang menerapkan nilainilai karakter, yaitu jujur, cermat, patuh, dan lain sebagainya. Hal tersebut sesuai dengan tujuan pendidikan sebagaimana yang tertuang dalam UU RI Nomor 27 tahun 2003 menyatakan bahwa: "Dalam Sistem pendidikan Nasional Pasal 40 ayat 2 dikatakan bahwa Pendidik dan tenaga Kependidikan berkewajiban meciptakan suasana pendidikan yang bermakna, menyenangkan, kreatif, dinamis dan dialogis. Rencana pembelajaran itu disusun setiap kali pertemuan ataupun beberapa kali pertemuan yang didalamnya terdapat standar kompetensi, kompetensi dasar, indikator, materi pokok, alokasi waktu, dan lain sebagainya yang perlu dipaham bagi seorang guru" 
Pendidikan mempunyai banyak masalah yang sering dihadapi oleh guru maupun peserta didik itu sendiri yang diawali oleh kemampuan dari guru yang kurang berpengalaman mengajar dan tidak mempunyai kemampuan dalam menyususn rencana pembelajaran. Ditambah lagi dengan adanya rencana pelaksanaan pembelajaran yang menerapkan karakter. Ini merupakan beban lagi bagi seorang guru dalam menyusun rencana pelaksanaan pembelajaran itu sendiri.

Pemahaman peserta didik dalam mempelajari mata pelajaran, melalui ungkapan kata dan kalimat seorang guru memaparkan materi kepada para peserta didik dengan menggunakan bahasa yang baik sesuai dengan ketentuan yang berlaku. Penggunaan bahasa Indonesia dalam menyampaikan materi pembelajaran, dengan pemahaman akan bahasa sangat menunjang keberhasilan proses pembelajaran, guru dituntut dapat menyusun RPP yang berkarakter serta menyenangkan para peserta didik melalui berbagai cara dan metode yang dapat dikembangkan para guru. Metode yang dapat di gunakan adalah metode Tanya jawab, diskusi, atau metode bervariasi. Departemen Pendidikan Nasional Direktorat Jendral Pendidikan Dasar (2004) mengemukakan bahwa : "Salah satu kritik yang paling menarik terhadap sistem pendidikan kita antara lain adalah pendidikan kita terlalu mementingkan pendidikan akademis, dan kurang diimbangi pendidikan karakter, budi pekerti, akhlak, moral dan mental seni dan olah raga. Untuk apa menciptakan anak yang pintar, jika tidak dilengkapi dengan karakter yang kuat, budi pekerti yang luhur, akhlak moral dan mentalitas yang tinggi”.

Hal tersebut menunjukkan bahwa kemampuan guru dalam menyusun rencana pelaksanaan pembelajaran (RPP) yang berkarakter memiliki peran yang penting dalam menunjang suksesnya proses pendidikan. Hal ini juga yang menarik perhatian peneliti untuk mengkaji lebih mendalam tentang kemampuan guru terkait dengan penyusunan rencana pelaksanaan pembelajaran. Identifikasi masalah dalam penelitian ini adalah untuk (1) bagaimana kemampuan guru sangat kurang dalam menyusun Rencana Pelaksanaan Pembelajaran berkarakter, (2) bagaimana anggapan guru bahwa RPP sebagai administratif sekolah yang harus di penuhi pada saat supervisi, (3) bagaimana penggunaan kata kerja operasional sangat minim bagi guru, (4) mengetahui kurangnya penerapan latihan yang mendorong kegiatan kerja guru terutama dalam penyusunan RPP berkarakter, (5) kurangnya kemampuan dari guru yang berpengalaman, (6) bagaimana rencana pelaksanaan pembelajaran yang menerapkan nilai-nilai karakter. Sedangkan Tujuan Utama dari penelitian ini adalah untuk mengetahui implementasi RPP yang karakter dalam pembelajaran IPS Terpadu.

\section{METODE PENELITIAN}

Penelitian ini menggunakan, penelitian yang bersifat deskriptif. Penelitian deskriptif adalah jenis penelitian kualitatif non hipotesa, Dalam penelitian ini yang menjadi objek penelitian adalah guru bidang Studi IPS Terpadu di SMPN 1 Unter Iwes dan SMPN 2 Unter Iwes dalam penyusunan RPP Berkarakter. Pengumpulan data dilakukan dengan cara: wawancara dan dokumentasi. Data yang diperoleh dianalisis dengan cara: menyeleksi data, klasifikasi data, dan penarikan kesimpulan. Sedangkan untuk mendapat keabsahan data dilakukan trianggulasi sumber, ketekunan pengamatan.

\section{HASIL PENELITIAN}

Dari hasil penelitian di SMPN 1 dan SMPN 2 Unter Iwes di dapatkan data bahwa guru-guru IPS mampu menjelaskan secara teori. Komponen RPP karakter dianggap sama dengan RPP sebelum berkarakter, para guru tidak diperjelas bagaimana cara penyampaian karakter pada saat penyusunan RPP berkarakter. minimnya pelatihan yang diikuti oleh guru-guru, mengakibatkan kemampuan dalam merancang pembelajaran masih kurang maksimal, dalam hal ini dari pinak diknas pendidikan sendiri sangat jarang mengadakan hal semacam pelatihan apalagi bagi guru yang baru belajar-mengajar, hal ini sebenarnya sangat penting dalam menunjang guru-guru dalam meningkatkan kemampuan guru dalam 
menyusun RPP berkarakter. Mengingat RPP adalah salah satu acuan bagi guru untuk menghasilkan pendidikan yang berkualitas.

Kemampuan guru dalam menyusun RPP berkarakter masih kurang, dari apa yang menjadi peraturan kurikulum yang berlaku saat ini, bahwa seorang guru harus profesional dalam melaksanakan tugasnya. Salah satu tugas penting bagi seorang guru adalah menyususn rencana pelaksanaan pembelajarannya.

RPP berkarakter merupakan acuan dasar setiap guru dalam menyampaikan suatu materi pembelajaran, RPP berkarakter merupakan alur yang harus diikuti agar pada saat mengajar tidak keluar dari materi yang diajarkan kepada peserta didik.

Penerapan nilai karakter harus dimulai sedini mungkin sejak anak terlahir ke dunia. Hal ini akan lebih mudah mengarahkan peserta didik dalam tingkat pendidikan selanjutnya sehingga tujuan pendidikan akan lebih tercapai.

Bergantian kurikulum yang dimaksudkan untuk perbaikan dan penyempurnaan kualitas pendidikan pada realitasnya kadang tidak berimbas nyata terhadap peningkatan mutu pendidikan kita.

Adanya pergeseran sikap atau prilaku peserta didik diantaranya kurangnya pegangan terhadap agama, kurangnya efektifitas pembinaan moral oleh orang tua, sekolah, maupun masyarakat itu sendiri. Sehingga dengan munculnya hal-hal tersebut salah satu caranya adalah dengan menerapkan pendidikan berkarakter, dengan demikian peserta didik mampu memahami dan memiliki karakter yang baik sehingga guru-guru mampu meciptakan pembelajaran yang berinovasi.

Mengimplementasikan program pembelajaran yang sudah dituangkan di dalam silabus, guru harus menyusun Rencana Pelaksanaan Pembelajaran (RPP). RPP merupakan pegangan bagi guru dalam melaksanakan pembelajaran baik di kelas, laboratorium, atau lapangan untuk setiap kompetensi dasar. Oleh karena itu, apa yang tertuang di dalam RPP berkarakter memuat hal-hal yang langsung berkaitan dengan aktivitas pembelajaran dalam upaya pencapaian penguasaan suatu kompetensi dasar.

\section{PEMBASAN}

Dalam proses pembelajaran semua guru mengajar menggunakan RPP berkarakter, hal ini dilakukan dikarenakan RPP berkarakter merupakan acuan utama dalam pembelajaran yang harus ada dan dimiliki oleh masing-masing guru agar materi yang disampaikan terarah dengan baik sehingga mampu menciptakan kondisi pembelajaran yang efektif. Selanjutnya mengenai pelatihan dalam penyususnan rencana pelaksanaan pembelajaran yang masih kurang, sehingga kemampuan guru dalam menyususn RRP berkarakter masih belum maksimal. Kendala yang sering dialami oleh guru-guru dalam penyusunan indikator dan tujuan pembelajaran yang harus sesuai dengan standar kompetensi dan kompetensi dasar pada silabus pembelajaran apalagi dengan munculya penerapan nilai-nilai karakter pada penyusunan rencana pelaksanaan pembelajaran (RPP).

Berdasarkan hasil analisis dokumen konsep pendidikan karakter ke dalam RPP berkarakter menurut peneliti telah terintegrasi di dalamnya jika RPP berkarakter telah mencakup pengetahuan (kognitif), sikap (afektif), dan keterampilan (psikomotor). Untuk menegaskan ketercapaian tujuan pengembangan karakter maka pendidikan merekomendasikan agar ada tambah rumusan dalam indikator dengan indikator pencapaian karakter.

Berdasarkan hasil analisis implementasi pendidikan karakter di sekolah tidaklah segampang seperti yang direncanakan di atas kertas. Berikut beberapa faktor sulitnya mengimplementasikan pendidikan karakter dalam proses pembelajaran.

Kepala sekolah masih bersikap diskriminatif dalam memberikan kesempatan untuk mengikuti pelatihan mengenai pendidikan karakter. Seorang pemimpin seharusnya memahami kebutuhan pembangunan kapasitas guru, serta staf dapat secara adil diberikan kesempatan peningkatan wawawasan dan keterampilan dalam pendidikan karakter khususnya dalam merencanakan pembelajaran. 
Era reformasi, telah merubah kehidupan sekolah. Kalau dulu peserta didik hukuman fisik merupakan pemandangan sehari-hari dalam kehidupan sekolah. Hukuman tersebut biasanya dilakukan sebagai upaya guru membentuk disiplin peserta didik. Namun sekarang hukuman fisik tidak diperbolehkan lagi, dimulai dari hal kecil saja misalnya guru melotot kepada peserta didik sebagai pertanda marah tidak diperbolehkan, karena dianggap melanggar Hak Asasi Manusia (HAM).

Kemampuan guru dalam mengiplementasikan RPP berkarakter dalam proses pembelajaran belum mampu dilaksanakan dengan baik. Sebagian guru dalam penilaian hasil belajar masih relatif rendah. Hal ini mengindikasikan perlunya peningkatan pengetahuan dan keterampilan Guru dalam mengembangkan dan melaksanakan penilaian kelas, sebagai upaya untuk meningkatkan kualitas pembelajaran.

\section{KESIMPULAN DAN SARAN \\ Kesimpulan}

Kesimpulan yang dapat diperoleh dari penelitian ini antara lain: pertama rencana pelaksanaan pembelajaran berkarakter pada mata pelajaran IPS Terpadu yang disusun oleh guru telah dilaksanakan karena telah mencakup unsur-unsur esensial rencana pelaksanaan pembelajaran yaitu : (a) identitas mata pelajaran, (b) standar kompetensi, (c) kompetensi dasar, (d) indikator, (e) karakter bangsa, (f) tujuan pembelajaran, (g) materi pembelajaran, (h) sumber belajar, (i) metode pembelajaran, (j) media pembelajaran, (k) langka-langka pembelajaran, (l) penilaian, akan tetapi nilai-nilai karakternya tidak diimplentasikan pada saat belajar mengajar dan tidak dibuat tabel observasinya. Kedua Faktor pendukung dan penghambat guru dalam menyusun Rencana Pelaksanaan Pembelajaran yang berkarakter pada mata pelajaran IPS Terpadu sebagai berikut : (a) Faktor pendukung : tersedianya media pendukung disekolah, misalnya melalui media internet, guru dapat dengan mudah memahami RPP bernilai-nilai karakter dalam proses pembelajaran IPS Terpadu, sebagian besar guru yang sudah bisa membuat sendiri RPP bernilai-nilai karakter tidak segan untuk membantu guru lain yang belum memahami RPP berkarakter bangsa. (b) Faktor penghambat : pendidikan karakter tidak dirancang sesuai dengan karakter yang diharapkan pada peserta didik yaitu setiap karakter yang dicantumkan pada RPP berkarakter harus dibuat tabel observasi supaya guru dengan mudah menilai karakter peserta didik. Dalam rencana pelaksanaan pembelajaran bernilai-nilai karakter yang dibuat guru belum mencakup 3 ranah yakni ranah kognitif, afektif, dan psikomotor. Guru hanya menyusun tujuan pada aspek kognitif saja, sehingga aspek sikap kurang diperhatikan. Dalam melakukan proses pembelajaran sebagian guru sering terpaku oleh buku, akibatnya tenaga pengajar bukan pada pembelajaran produktifitasnya. Selain itu pihak sekolah masih sangat jarang memberikan pelatihan atau supervisi mengenai penyusunan RPP bernilai-nilai karakter ini, akan tetapi banyak melihat cara penyampaian materi saja.

\section{Saran}

Pertama diharapkan sering melakukan pelatihan ataupun supervisi terhadap guru mengenai hal tersebut, karena dengan kemampuan guru yang baik akan meningkatkan hasil pembelajaran peserta didik dan mutu sekolah. Kedua kepada guru pengajar khususnya guru IPS Terpadu untuk lebih kreatif dan mandiri dalam menyusun rencana pelaksanaan pembelajaran bernilai-nilai karakter dan betul-betul diterapkan pada saat proses belajarmengajar berlangsung sesuai dengan materi yang akan ajarkan, sehingga tujuan pembelajaran dapat tercapai dan peserta didik termotivasi dalam belajar dikelas. Ketiga kepada dinas pendidikan nasional agar tetap mengadakan pelatihan terutama pada saat penyusunan silabus dan rencana pelaksanaan pembelajaran. Peran MGMP perlu dioptimalkan dalam mengkaji perancangan dan pelaksanaan pembelajaran dikelas. Setiap Guru diharapkan dapat mengikuti program tersebut agar guru dapat mempelajari pedomanpedoman KTSP. 


\section{DAFTAR PUSTAKA}

Abdul Majid. (2011). Pendidikan Karakter dalam Persfektif Islam. Bandung: PT Rosda Karya

Abdullah Munir. (2010). Pendidikan Karakter. Yogyakarta: PT Pustaka Intan Madani

Agus Wibowo. (2012). Pendidikan Karakter: Strategi Membangun Karakter Bangsa Berperadaban. Yogyakarta: Pustaka Pelajar

Akhmad Muhaimin Azzet. (2011). Urgensi Pendidikan Karakter di Indonesia: Revitalisasi Pendidikan Karakter terhadap Belajar dan Kemajuan Bangsa. Yogyakarta: ArRuzz Media

Arif Rohman. (2009). Memahami Pendidikan \& Ilmu Pendidikan. Yogyakarta: LaksBang.

Darmiyati Zuchdi. (2011). Panduan Implementasi Pendidikan Karakter Terintegrasi dalam Pembelajaran dan Pengembangan Kultur Sekolah. Yogyakarta: UNY Press

Djohar. (2006). Guru Pendidikan \& Pembinaan, Penerapannya dalam Pendidikan dan UU Guru. Yogyakarta: CV. Grafika Indah.

Doni A. Koesuma. (2007). Pendidikan Karakter. Jakarta: Grasindo.

Ichas Hamid. (2006). Pengembangan Pendidikan Nilai dalam Pembelajaran Pengetahuan Sosial di SD. Jakarta: Erlangga

Isjoni. (2006). Gurukah yang dipersalahkan:Menakar Posisi Guru di Tengah Dunia Pendidikan Kita. Yogyakarta: Pustaka Pelajar.

Margono. 2000. Metodologi Penelitian Pendidikan. Jakarta: Rinekacipta.

Soetjipto \& Raflis Kosasi. (2009). Profesi Keguruan. Jakarta: PT Rineka Cipta

Suryo Subroto. (1997). Proses Belajar Mengajar. Jakarta: Rineka Cipta

Suryo Subroto, B. (2002). Proses Belajar Mengajar di Sekolah. Jakarta: PT. Rineka

Suparlan. (2006). Guru Sebagai Profesi. Yogyakarta: Hikayat Publishing

Suyatno. (2008). Panduan Sertifikasi Guru. Jakarta: PT Indeks

Swasto, B.S. (1996). Pengembangan Sumber daya manusia, pengaruhnya terhadap kinerja dan imbalan. Malang: FIA-Unibraw.

Zaini Hasan. (1996). Pengantar Ilmu Sosial. Jakarta: Depdikbud. 